\title{
EVALUATING THE WORK OF SINGAPORE'S Malay-BASED ORganisations IN RAISING THE EDUCATIONAL ATtAinMENT OF THE ETHNiC COMMUnity: A CONTINUING ANALysis
}

\author{
Shamsuri Juhari ${ }^{\mathrm{a}}$ \\ SIM University
}

\begin{abstract}
Statistics indicate that demographically, Singapore's minority Malay community, unlike the other ethnic groups in the small multicultural, multi-religious island-state, has yet to 'mature' and contribute fully to the country's economy. A subsequent argument is thus made on the need to ensure that learners from the community be developed in the best possible way so as to maximise their potential capacity and thus value-add to the nation's growth. A discussion on the various issues affecting Malay educational attainment is made as preface to the ensuing review of past programmes undertaken by local Malay organisations to improve the situation. The article will conclude by proposing further approaches to collectively raise the educational attainment of the ethnic group.
\end{abstract}

KEYWORDS: Malay educational attainment, integration and consolidation, conscientisation process, Singapore

\section{Introduction}

Official statistics indicate that the minority Malay community of Singapore, unlike the other ethnic groups in the small nation-state, has yet to mature and contribute fully to the country's labour force. By 2014, the Malay population in Singapore stands at 516,657 comprising 13.3 per cent of the total resident population (Department of Statistics, 2015). Malays form the second largest cluster with the Chinese forming the biggest group. Today, the population structure, in general, has advanced from one that has a large base to one that is becoming narrower, with an upwards bulge taken up by those in the working ages. The Malays nevertheless, are still the youngest demographic group in the country, with an average median age of 31.4 years compared to the national median age of 37.4 years (AMP, 2012).

Currently, 22.4 per cent of Malays are in ages below 15 years compared to 17.4 per cent at the national level. This implies that the larger proportion making up the community have yet to enter the nation's work force compared to the already falling share from the other ethnic communities. It bodes potential for the ethnic community to be a significant contributor to the country's economic production in about 10-15 years down the road. As already pointed out by many of the nation's commentators, the future development of the country will very much depend on how the government builds up the quality of our youths today. In this respect, attempts at enhancing the educational achievement of youths from the Malay community must be considered a national priority.

As a group where a majority of its members has still to reach full adulthood, the Malays as a community face many challenges such as young working parents having to juggle the burdens of guiding and supporting their children as compared to the other ethnic groups making up the population (conversely, the same set of data shows the other ethnic communities being burdened with taking up the task of supporting their elderly). Another challenge arises from the effect of the

Correspondence can be directed to: shamsurij@gmail.com 
government allowing for a greater influx of better educated individuals emigrating from countries ethnically associated with the Chinese and Indians. This has resulted in the aggregate achievements of these communities being inadvertently inflated in contrast to the Malays. Unfortunately, these factors combined have contributed towards making the effort required of the latter to uplift their status all the more difficult. As will be discussed further into this article, factors such as these serve to fuel the negative self-image already prevalent among members of the Singapore Malay community.

The current demographic advantage presenting itself to the Malay community should provide an excellent opportunity for leaders of the ethnic group to take up the challenge of improving the educational achievements of its youths and thereby ensuring that a quality workforce gets developed in the near future. One way of tackling this issue is to understand the reasons for the weakness by looking into the community's origins and the subsequent challenges that evolved from it.

\section{The Singapore Malays}

A majority of Singapore's Malay community are able to trace their origins to Java, Indonesia with an additional 15 to 20 percent from Bawean Island, situated in the Java Sea, north of the city of Surabaya (Aljunied, 2002). The Javanese settled down during the period of British colonial rule from the midnineteenth century to just after World War II as they were attracted both by urban wages promising a higher standard of living as well as release from the constraints of their native villages where they were often able to only occupy the lower rungs of the economic and social order. Officially, the Singapore government defines being Malay as any "persons of Malay or Indonesian origin, such as Javanese, Boyanese, Bugis, etc." (Singapore Department of Statistics 2010, p. 181). This implies that, similar to the Chinese and the Indians, members of this ethnic group are also descendants of immigrants and thus share similar historical status. The difference however, lies with the fact that unlike the other ethnic groups in the nation-state, the Malays are recognised as the indigenous inhabitants of the land as their ancestors came from within the region, specifically peninsular Malaysia, Sumatra, Java, and the other islands of the Indonesian archipelago. This recognition is enshrined in Article 152 of the Constitution of the Republic of Singapore (Attorney-General Office of Singapore, 1965).

Alatas (1977) observed that in the past, the British colonialists had looked upon the Malays of Malaya, which then included Singapore, as simple farmers and fishermen with strong religious faith and a 'racially-inherent' tendency toward loyalty and deference to authority. It provided justification for them preferring to recruit Malays for positions in the police and armed forces, and for unskilled positions in the public service. An official government census conducted in 1931 reflected that 18 percent of Malays at the time earned their living as fishermen while another 12 percent worked as farmers. An overwhelming 70 percent however held jobs in the urban cash economy; either in low ranking public service positions or as gardeners, drivers, or small-scale artisans and retailers (Vlieland, 1932).

Three decades on, data collected in 1961 recorded similar figures with more than half of Singapore Malays depending on employment in the public sector (Singapore Department of Statistics, 2009). Malay identity however had, by then, evolved to become one that is increasingly couched in religious terms, with Malay being taken almost as a synonym for being Muslim, and with most Malay organisations taking on a more religious facade (Lian, 2001).

Unfortunately, as pointed out by Imram Mohamed, Chairman of the Association of Muslim Professionals, although very much a part of Singapore's modernising society, it has become obvious that the Malays, as a minority ethnic group, are today seen by others as still occupying the bottom rungs of the country's socio-economic ladder (Association of Muslim Professionals, 2006).

\section{The 1980 Census Results}

The lag especially in the educational front was finally discussed openly as a result of the 1980 census results. While initially talked about by government and community leaders in 'hushed' tones due 
to political sensitivities and in not wanting to emphasise the racial divide, the issue of the Malays being a 'less progressive' community became a topic of national debate after the census results were published. In a speech commending the achievements of a government supported Malay organisation during its 25th Anniversary Dinner and Awards Presentation (AsiaOne News, 2007), Mr. Lee Hsien Loong, the country's Prime Minister reflected on statistics which then painted a gloomy picture:

- $\quad$ Only one in six Malay students were able to attain five ' $O$ ' level passes at the GCE ' $O$ ' examinations ${ }^{1}$.

- Only 1.5 percent of all university graduates and 2.5 percent of students enrolled for higher education were Malays.

- $\quad$ Only eight percent were considered to be professional and technical workers (including school teachers).

- $\quad$ Only two percent of all administrative and managerial posts were held by Malays.

- Malays were dropping out of the competitive school system in large numbers while those who managed to continue past primary school were mainly concentrated in vocational education programs largely associated with underachievers.

Additional statistics also indicated that while 86 percent of the Malay work force was employed in the clerical, service, and production sectors at the time, these were basically low-skilled and lowsalaried positions. For instance, according to data from the manufacturing industry, 45 percent of all employed Malays then only worked on assembly lines and mostly in foreign-owned electronics factories.

These disappointing statistics led to government leaders' realising the potential threat posed by the close association between Malay ethnicity and low educational achievement and occupational status. The issue became even more jarring when observers point out that on a wider scale, the socio-economic progress of the Malays has continuously remained statistically poorer when contrasted against the progress of the Chinese and Indian communities along the same range of indicators (Singapore 2025, 2011) The community's lag in educational attainment is seen as a major contributor to this problem. Leaders from the ethnic group began to make clearer their demands to ensure progress for its members. Debates in Parliament, for instance, put forward questions such as what more can be done to help Malay students' progress at the same rate, if not better, compared to their peers from the other race groups (Bland, 2010).

The sudden thrust in highlighting issues faced by the Malays in effect led to a renewed sense of urgency in looking for possible ways to resolve the community's woes. In 1982, the authorities finally declared the Malays' educational difficulties a national problem which justified government-backed action to improve their academic performance (Suratman, 2004). Considered a landmark decision, the event denotes a turning point where numerous government-initiated or government-sanctioned strategies aimed at resolving the situation were put in place. These included exchanges resulting in the formation of Mendaki, a pioneer self-help group 'dedicated to empower the community through excellence in education in the context of multi-racial and multi-religious Singapore' (Yayasan Mendaki, 2015).

\section{Issues Impacting Education of the Singapore Malays}

A number of theoretical frameworks have surfaced to explain the lag in the educational achievements of the Malays in Singapore. This section attempts to briefly touch on discussions which relate primarily to the interplay of behavioural and cultural construction as well as the unintended consequences of the nation's structured education landscape. 


\section{Behavioural and Cultural Construction}

Analysts mention that because Malay students come from a very low base, many are still trapped by the vicious cycle of poverty where their families have been in for generations. Students from low socio-economic background's responses to education are shaped by the limitations they face in their lives. In explaining how personal motivations and responses are shaped, Anthony Giddens (1991) points out that humans are not passively shaped by social or cultural phenomenon. Instead, we react intentionally and this in turn impacts the construct of our individual identity. The self-identity which is eventually formed is therefore the product of a person's own reflexive understanding of his or her history. Giddens makes it clear that while self-identity cannot easily be changed at will, it is nevertheless fluid in nature and alters depending on the person's reflexive beliefs about her or his own biography.

Malay students suffering from low economic status are severely handicapped in the way they respond to life's challenges due to the lack of resources or support at their disposal. They are hampered by a system which favours and places in great esteem theory-based learning in contrast to hands-on learning, an alternative more suitable for those from less advantageous backgrounds. Following Giddens' theoretical framework, the current situation translates to these lesser performing students perceiving only a very limited circumference of opportunities for themselves and this is reflected in their subsequent lack of motivation to perform.

In addition, these Malay students, more often than not, also belong to families which are caught in a vicious cycle. This is primarily because they do not have the same resources as other families to break out of the phase. The cycle, for example, begins with a crisis, such as teenage pregnancy or substance abuse, which financially stable families can resolve because structurally, they will have ready access to the needed resources. Poorer families on the other hand have far fewer options. When faced with such crisis, individuals from these backgrounds tend to develop a fatalistic mind-set which, due to structural circumstances such as not having access to an effective financial and emotional support network, no longer sees value in long term sacrifices necessary to attain educational achievements. This is especially since these are no longer seen as achievable investments. The pressures of a continued mismatch between what they see as the prevailing expectations of society and the 'futility of life' they are trapped in activates a form of coping mechanism that leads to the creation of mental models based on an easier-to-accept culture and ideology of poverty. This is evident from the responses collected during a series of dialogue sessions previously conducted with local Malay youths. When asked for their insights on why the community has not been progressing, an enlightened participant reasoned that "We stick together and we feel comfortable. I think that may be the reason why we are too comfortable. Why we are so ignorant. Why we are so alah kadar ('mediocre', implying very lowly in expectations)" (Juhari 2012, p.177). The response tells of a situation where members of the Malay community tend to reinforce each other's negative perceptions of themselves and their ethnic group. This cumulatively results in a community suffering from a defeatist mind-set possessing low aspirations for themselves.

The pervasiveness of such a worldview results in a community plagued by weakened capacity both to dislodge persistent negative beliefs and to mitigate the ensuing self-fulfilling prophecies. These are combinations which serve to sustain stubborn social inequalities. Regrettably, these families fall deeper into the 'abyss' as such mind-sets exposes them to further risks of impoverishment and lowered educational opportunities. Fatalistic clichés such as 'it's fated', 'it's God's will' or 'what will be, will be' become a cherished albeit misconstrued notion. This cycle, if deprived of any forms social intervention, unfortunately tends to run over generations.

\section{Education Landscape}

In an ethnographic study focusing on the Malay Underclass by Mokhtar et al (2012), researchers came to the conclusion that Singapore's education system caters to the mainstream with only few 
advantages allocated to those at the bottom end. They cite this as adding to the woes of a community already finding it difficult to break-free from the low income trap. This notion is shared by other scholars who opined that despite key themes such as globalisation, diversification, differentiation and segregation being the formulaic mainstay of the country's education planners, what is now becoming explicitly specific to members of Singapore's Malay community is that outcomes are no longer level. Several reasons for this have been highlighted. For instance, the introduction of the streaming process $^{2}$ in the education system since three decades ago have resulted in several generations of Malay parents managing to graduate only from the slower or less prestigious tracks due to their disadvantaged socio-economic backgrounds. The cohort will then proceed to secure employment with jobs from the lower end of the career ladder. Unfortunately, the experiences of these parents make them less well-equipped both with the know-how and resources to prepare their own children for the challenges of the current education system. In fact, over the years, these parents are made more disadvantaged due to the continuous refinements and increased sophistication imposed upon the streaming process. With the advent of curriculum niches, specialised schools, integrated programmes, flexible streaming, and direct school admission, the Singapore education landscape has made itself far too complex for such parents to comprehend, let alone act as effective guides to their children (Tan, 2010). Critics have even argued that Singapore's much lauded meritocratic educational approach have now degenerated into a form of 'parentocracy' where academic success no longer hinges solely on pupils' merit or hard work but increasingly on the knowledge, resourcefulness and extent of involvement of their parents (Ong, 2014).

\section{Classroom Supplementation as an Immediate Strategy}

While Mendaki is not the first Malay organisation to be established to serve the needs of the Malay community, it is nonetheless the first that is fully backed and predominantly funded by the government. This was at a time when there was finally open consensus on the need to overcome the deficiencies experienced by the community. Immediately, plans were made to try and raise the level of educational attainments of the ethnic group. Formed in 1982, the Malay self-help group immediately implemented its community-wide education programme. Primarily, this came in the form of the Weekend Tuition Scheme. Today, this is seen as a 'stop-gap' measure to raise the educational capability of the Malay community. Other Malay organisations soon came in full force with similar programmes. Jamiyah, another Malay organisation for instance, revitalised its 'Lenda-Hand' project targeting Malay youths and was rewarded with many of its student-participants achieving favourable results in their examinations (Jamiyah, 2014). There is even a joint initiative involving three Self-Help Groups which cater each to the needs the Malay, Chinese and Indian communities respectively. Under the Collaborative Tuition Programme (CTP), Mendaki, the Chinese Development Assistance Council (CDAC) and the Singapore Indian Development Association (SINDA) came together to offer tuition to students of all ethnic groups. Currently offered at 61 selected Tuition Centres, CTP was launched in 2002 to allow students to "take part in tuition programmes offered by other self-help groups, optimising the use of community resources and providing more convenience to students from less well-to-do families" (Goy, 2013).

\section{Subject Mastery}

Despite the heavily subsidised tuition service offered to students from the community, it dawned on the leaders that Malay students seem to be particularly weaker in certain subjects, specifically Mathematics and English. The question arose as to what other initiatives can be introduced to assist students in overcoming such deficits. An obvious answer then was that efforts should be directed at subject mastery.

By 2012, new initiatives such the Reach-out, Progress and Excel (RoPE) Programme were introduced by Mendaki in several primary schools. Targeting the learning of Mathematics, the 
programme provided tips and strategies for Malay students to better appreciate and understand the subject. Other programme variations depending on target groups followed suit. For example, the 3M (Maju Minda Matematika) programme was introduced to equip parents with skills they can use to coach and motivate their children into mastering the subject at home.

Subsequently, other programmes were introduced to target mastery of other subjects like English. For example, Mendaki spearheaded the Read-with-Me Parent Training Programme for English. Similarly, the Association for Muslim Professionals (AMP) introduced the Partners in Learning Workshop catering to students with the aim of enhancing their subject mastery in English. In time, other Malay self-help groups also organised writing and creativity courses with the same objective in mind.

\section{Developing Resilience}

With a better understanding of educational psychology, it became increasingly clear to Malay thought leaders that tuition and subject intensive enrichment classes, although well received, have still not been able to create sufficient positive impact on overall student grades. It led to discussions that the current external 'push' approaches needed to be complemented with internal 'pull' strategies. It was felt that instead of being told to, Malay students needed to be inspired to want and achieve success for themselves. Affective-based programmes aimed at developing resilience were then introduced targeting students from difficult backgrounds. For instance, in 1993, the AMP introduced a programme called Dr Bola or The Soccer Doctor Programme ('AMP Rancang Luas Projek Dr Bola' AMP Plans to Expand Soccer Doctor Project, 1993). The target group was students from the Institute of Technical Education (ITE) and while the 'carrot' to the players was the delight in taking part in the coaching and practice matches, it was the subtle sharing sessions conducted prior to the game and even during the warm down sessions that made much impact. During these 'teachable' moments, positive character building messages are discussed and subconsciously instilled into the participants. A version of the programme involving more suitable activities for girls was later introduced under the label the 'DNA' Programme (Developing New Aspirations). 4PM, another Malay organisation, has also been recognised for its success in creating the 'BITE' (Bestari or 'Smart' ITE) Programme targeted at building resilience among these youths. To cater to students who are even more in the 'at-risk' category, Mendaki has taken the lead in collaborating with other Malay organisations to organise a series of impactful activities under the 'Max-Out' Programme. The programme provides a second chance for out-of-school youths to get back into the classroom to receive formal education. Max Out adopts a holistic approach 'by combining academic instruction with character development to provide the best possible support for these youths to realise their potential' (Yayasan Mendaki, 2015).

Even students who are considered 'safe' are not forgotten as the objective is for them to reach even greater heights. For this group of students, AMP introduced the 'SWAT' (Speakers, Writers and Thinkers) Programme targeting secondary one to four students from the Express Stream (refer to streaming process). Based on the same objectives, other programmes which have been conducted include the 'Empowerment for Girls' and 'Engagement for Boys' series under Mendaki, and the 'Youth in Action' Programme managed by the Community Leaders Forum (CLF). The Islamic Religious Council of Singapore (MUIS) even got into the picture with the success of their aLIVE (Learning Islamic Values Everyday) workshops. These events are aimed at strengthening spiritual and physical development so as to create responsible Muslims who excel in their education.

\section{Motivation and Mentorship}

Inspiration needs to be sustained. With this in mind, programmes aimed at instilling this positive quality were subsequently introduced. The list now includes Mendaki's Talent Development Programme catering to better achieving students with the hope of driving them towards higher levels 
of achievement. Motivational talks, examination preparation programmes, and career awareness presentations were regular features organised to ensure that Malay youths remain inspired to achieve academic success. In addition, youth leadership programmes designed and conducted by Malay organisations such as Taman Bacaan (Reading Garden) ensures that participants remain focussed in wanting to achieve the best for themselves. Even neighbourhood mosques contributed to the effort by organising holiday programmes aimed at instilling positive values which will motivate youths to strive hard in their faiths, in their studies and in life in general.

Another set of affective approaches introduced to Malay students is in the aspect of mentorship. In the context of Singapore's Malay youths, the mentorship approach exposes them to role models which they can look up to and where the transmission of positive values can be reinforced. Programmes based on the mentorship platform include Young AMP's Windows on Works (WOW) where junior college and madrasah (Islamic schools) students are paired up with young graduate professionals and Project Protégé by Mendaki which selects students already aspiring to be in particular vocations and attaches them to professionals who have already made their name in that field.

\section{Social Consciousness and Youth Activism}

The development of a socially conscious youth makes for an achievement-oriented learner. Based on this rationale, Ain Society designed and organised Kembara Perkasa, a programme involving humanitarian trips to lesser developed countries. In 2013 for example, a funded trip to Vietnam was organised involving visits to several orphanages in the country. Reflecting on the subsequent community service project that they had to complete, participants shared that they felt empowered having knowingly contributed to the betterment of others. The sense of pride in the successful completion of their 'mission' gave them renewed motivation to achieve success in all the other aspects of their life's efforts, especially those concerning their studies. Another example worth highlighting is the 'Praxis' programme, a joint Mendaki Club and Young AMP effort which was started in 2010 (Yayasan Mendaki, 2010). The 4 days/3 nights residential programme comprise a series of thought provoking and even 'confrontational' ${ }^{3}$ activities including visits to social welfare organisations. Positive results have been noted with some of its participants taking responsibility in designing and initiating their own community projects. As an intended benefit, many of these participants became each other's source of inspiration and motivation to further their studies so as to better serve humanity.

\section{The Malays Today}

Cumulative effects of the many intervention processes initiated for the Malay community since more than thirty years ago can now be examined. It can be said that the Malays of Singapore have today measurably improved their plight. Success in education has been translated into raised socioeconomic status of the ethnic community. A newspaper article published in The Straits Times (Wee, 2007) announced that there is now a growing Malay middle class displaying increased purchasing power. As more Malays are holding higher skilled and better-paying jobs, median incomes have correspondingly increased. Also, it has become evident that more Malay families have upgraded to better housing with the vast majority (93 percent) legally possessing their own homes. The proportion living in four-room or larger public housing flats and private properties has been raised by more than six times (from 11 percent in 1980 to 71 percent in 2005). There has also been a steady increase in Malay ownership of high-end consumer durables such as cars, air-conditioners, personal computers and mobile phones. Collectively, these indicators reflect a community enjoying higher living standards and a better quality of life. 


\section{Persistent Gaps}

Unfortunately upon closer scrutiny, the discerning observer cannot avoid noticing that these indicators of 'success' do not really reflect the true picture of the Malay community's achievements especially when compared to the progress shown by the other ethnic groups during the same period.

In 2014, Singapore's Ministry of Education released figures reflecting educational achievements over a 10-year period between 2004 and 2013. The statistics revealed that the percentage of Malay students who attained the distinctive $A$-star $\left(A^{*}\right)$ to $C$ grades in PSLE Standard Mathematics hovered between 55 and 60 percent, hitting a peak of only 61.1 percent in 2010. An issue of greater concern however is that on average, a whopping divide of more than 20 percent between the achievements of Malays and the rest in the country remains unchanged throughout the period (Ministry of Education, 2014).

The same set of statistics also reflect Malay students' performance in English Language as being continuously behind that of mainstream society. While the persistent gap is much smaller during the 10-years, it nevertheless provides very little comfort as the margin has been increasing to the current $5 \%$. It adds to the worry that the community will continue falling behind the other ethnic groups for the subject.

The failure to achieve credible results at the primary level occurs despite the fact that a high proportion of Malay students are made to enrol into the Learning Support Programmes (LSP). These are supplementary lessons offered to students in Primary One and Two targeting specifically those who face learning deficits in English and Mathematics. Based on MOE statistics, about 32 percent of pupils in the LSP were Malays (MOE, 2014). Bearing in mind that the Malays comprise less than 14 percent of the total population (Singapore Department of Statistics, 2009), this over-representation indicates that a substantial percentage of Malay students was not school-ready by the time they entered Primary One. Ahmad (2007) explains that this can be deduced from figures which showed that every year, an estimated 5 percent (or at least 2000 children) did not attend preschool prior to their entry into Primary One and it is believed that a majority of them were Malay students (MOE, 2006). Ahmad cites a previous study in $2003^{4}$ which indicated that Malay children who did not attend preschool education were shown to be at a definite disadvantage and were never able to completely catch up with their peers at the same level. Reasons cited by parents for not sending their children to kindergarten were mainly financial despite the availability of several preschool subsidies for low income families.

In one of its annually published Policy Digest, Mendaki highlighted statistics which reflect the underachievement of the Malays both at the education and socio-economic fronts. The Digest stated that 5.6 percent of Malay students who sat for their Primary School Leaving Examinations (PSLE) in 2005 failed to get the required grades to be eligible for secondary school. This figure is more than double the national figure of 2.2 percent for the same year. Furthermore, it was highlighted that out of the 1100 pupils who failed the PSLE in 2005, about 130 of them (or 12 percent) had failed the examination for the third time (Yayasan Mendaki, 2007). Again, the trend indicates that Malay students are likely the ones making up the bulk of this number. It becomes an issue of greater concern when one realises that the number of Malay students repeatedly failing the PSLE serves only to inflate the yearly figure.

Nonetheless, with the introduction of the 10-year compulsory education system allowing for differentiated tracks at the secondary level, many are now presented with the opportunity to advance their studies albeit at a slower pace (Hodge, 2007). This should then allow for greater numbers entering secondary schools. Expectedly, it translates to an increase with 85.6 per cent of Malay students admitted into secondary schools. Nevertheless, this is still a poor showing when compared to the more than 95 per cent entry rates shown at the national level. It indicates that many are still not able to attain the minimum required to advance their studies to secondary school.

Finally, when looking at the higher levels of education, it can be seen that more Malay students have done well enough in their exams to gain entry into the local universities. Unfortunately, the 
figures have only gone up from the 1.5 per cent in 1982 to the current 6.8 per cent. This is far below the 28.3 per cent entry rates reflected by the cohort from the other races (AMP, 2012).

The persistent underachievement experienced by students from the Malay community can be said to be the result of the multiplicity and interconnections of issues preventing these pupils from transforming their lives. Malay organisations such as Mendaki, AMP, Jamiyah and Ain Society have done much to contribute to the betterment of the Malay community. Through their efforts, a large segment of the community is said to be making steady progress. Yet, despite these, a significant proportion is still lagging behind in their studies. Malay organisations are very much handicapped in wanting to help students from the ethnic group achieve their best. As non-policy making bodies, they lose much of their effectiveness in being able to work only at the periphery of the existing education structure. Nevertheless, if looked at from a new perspective, there can be ways to resolve the situation.

\section{Integration and Consolidation}

The different approaches that have been introduced over the years by Malay organisations were crafted after looking at particular problems from all possible angles and attempting to achieve a solution through the variety and diversity of programmes currently available. These approaches are conceptually valid in their premise of elevating the educational achievements of Malay students and collectively raising the status quo of the ethnic community. Unfortunately, overall results thus far do not forward the promise that the ethnic group will experience success in the near future.

One way of analysing the shortcomings of the available programmes is to see them as merely piecemeal solutions attempting to resolve a presenting problem. Unfortunately, the difficulty being looked into is only part of a series of interrelated issues compounding the larger crisis. Cases of truancy, for instance, may on the surface, reflect the offenders' negative attitude towards classroom learning. Upon closer investigation however, one will usually discover other mitigating circumstances such as the parents not having enough money to contribute to the student's bus fare or even needing the child to stay at home so as to look after a younger sibling while they go to work.

Government agencies and social welfare organisations have been very active in providing assistance to individuals and family units experiencing difficulties. There are ready funds which can be disbursed based on the genuine needs of each case. However, in many instances, these services are unaware of the existence of the other. The programmes work in silos and are oblivious to the ways of how another operates in providing help to the families in need. In short, while the family unit accepts the best possible help from the relevant agencies, the aid that they receive tends not to complement or synergise. The school delinquent is counselled and made to undergo behaviour management programmes but little is done to ensure that the family be made more supportive of the child's education. Even if financial assistance is made available to the family, without proper guidance and supervision, the needed emotional support for the student may be lacking. In the end, there can be no win-win situation as the intervention lacks the holistic approach. Such attempts at helping the child will not lead to fruition as the bigger issues to do with the family do not come under the welfare organisation's purview and is subsequently ignored.

A possible solution can therefore be made by looking at ways to integrate and consolidate the existing forms of help made available by the Malay organisations. A framework underpinned by such an approach is depicted by one primary school's aftercare service for its students. The model is also known as the wraparound approach to education.

\section{The School-Based Wraparound Approach to Education}

The primary school had identified 8 Primary 1 students who were facing difficulties in adjusting to school life. These pupils were facing problems such as absenteeism, lack of family support, falling 
behind in their grades and poor attitude to their studies. As the students happen to be Malays, the school sought the assistance of a Malay organisation which subsequently enlisted the help of its partner organisations. A coalition made up of teachers of the school and various representatives from the Malay self-help group, a learning centre and a research centre was formed to craft an after-school care programme for this small group of Malay students. Apart from supplementary academic activities, the primary objective was to motivate these students to excel in their studies thus releasing them from the vicious cycle.

The first issue to crop up was that these students' families did not have the financial means to pay the cost of the after school care sessions. Though various funding schemes were available, none of these students qualified as their families did not fit into any of the required criteria. The primary school then offered the free use of a space at a corner of their library. Through generous private donations, daily lunch was provided. Realising that another obstacle was in the form of family members unable to find time to fetch these students after the care sessions, donors also paid for the cost of the school bus transporting these children back to their homes. The Malay selfhelp group paid for the learning centre to provide a trained tutor to supervise the students. At no additional cost, the learning centre also worked together with the other representatives to design a customised curriculum for the afternoon sessions. At the same time, the Community Services division of the self-help group was tasked to look into ways of helping the family unit under their existing programmes.

Once all was finalised, the after-school care programme kicked off with daily two-hour sessions conducted after the dismissal bell was rung. The young pupils are accompanied by their class teacher to the library and handed over to the after school care tutor. This provided an opportunity for the two teachers to interact and consult each other on the development of these students. Matters such as the list of spelling words for these students to master for their classroom lessons were conveyed so that the after school care tutor can take the opportunity to prepare these students better for such lessons.

At the time of writing, the programme is still in its infancy and though it is premature to announce any kind of concrete results, teachers, parents and students involved had provided favourable feedback during the preliminary interviews. The wraparound approach opens itself to further integration and consolidation by welcoming more parties involved in the process. A private vendor specialising in cognitive brain development for example, has approached the coordinators and offered to conduct several of their sessions on these students at a nominal price. The self-help group in turn has agreed to foot the cost. The vendor is now seeking the advice of the organising committee in designing the lessons. In addition, a group of concerned professionals is in the midst of setting up a 'mobile parent school'. Volunteer members intend to visit identified homes, engage parents, and provide advice and counselling regarding the well-being of their families. They believe that this will remove obstacles preventing busy or uninvolved parents from attending organised activities. The families of the 8 students in the programme will now be at the top of their list. Lastly, a group of teachers are organising themselves to act as 'bridging agents'. This comes with the realisation that being front liners in the classroom, they are in the best position to identify students in need and subsequently refer them to the relevant 'touch points' making more real the potential of the school-based wraparound approach. The first step for these educators, of course, is to familiarise themselves with the variety of help that is available to such students and their families.

\section{Developing 'Conscientised' Learners}

Another approach focussing on the principle of integration and consolidation of existing programmes can be related to the process of developing conscientised learners. According to Freire (1973, p.51), conscientisation is a particular kind of critical consciousness stemming from a recursive process of "reflection and action" targeting individual and social transformation. If we contextualise it to issues facing the Malay community, it can be seen as initiating a process where members reinterpret their 
observations and experiences and begin to question their community's reactions to social challenges. Conscientisation is a mark of capacity building for critical thinking where the individual begins to question the state of affairs; where he or she no longer accepts the situation and wants to change it for the better. It leads to renewed aspirations for youths of the Malay community and triggers actions for improvements in their personal lives with the hope that their actions will collectively contribute to the betterment of the community.

Research on the conscientisation process in the context of Singaporean Malay youth have resulted in a framework which proposes exposing them to five core experiences - 1. Dialogue, 2. Reflexive learning 3. Interculturality 4.Empowerment and ownership, and 5. Mentored leadership (Juhari, 2012). Individually, these experiences are already made available via the variety and diversity of programmes currently organised by Malay organisations. For example, it was previously mentioned that the Kembara Perkasa Programme allows its participants to experience elements of reflexive learning by providing opportunities for them to observe and contribute to the betterment of the communities that they visit. The next move, based on the framework, is for these youths to undertake further activities which underpin the other stated core experiences. This can perhaps take the form of an interfaith programme that allows participants to practice dialogue and experience interculturality. What is lacking however, is a mechanism that functions to facilitate these youth' integration and consolidation of these experiences.

A proposed solution lies in the form of a cyber-tracking system where participants are provided with an online platform where they can reflect, record and share as they undergo various experiences in the four or five years of their secondary schooling. These youth thus remain motivated to avail themselves to as many of these experiences by participating in programmes managed by Malay organisations.

\section{Conclusion}

In the book Scarcity: Why Having Too Little Means So Much (Mullainathan and Shafir, 2013), the term 'bandwidth' was used to explain the idea of mental capacity. In the context of poverty, limited 'bandwith' indicates that because of the life situation that they are in, the poor are limited in their mental capacity to think and do many of the things the rest of us consider routine such as going to work regularly and punctually, pursuing higher education, getting a professional degree or spending money without having to worry about having enough at the end of the month. This inability to think critically is compounded by the daunting processes imposed when requesting for assistance such as the need for meticulous information and detailed documentary evidence. This is very much a disincentive for needy individuals. In the case of the lesser performing Malay students, it becomes another retarding factor preventing them from seeking and receiving the help which can allow them to focus on their studies.

Take for example, the case of the eight students involved in the after school care project mentioned earlier. When their parents were asked why they did not previously attempt to apply for financial assistance, the reply was that it took too much work and thinking. Also, from their experience, the effort was often futile. Rather than relying on quality care provided by the after school programme, they therefore chose the lesser demanding means in obtaining the services of a caretaker. Usually, this comes by way of arranging for an older sibling or grandmother to take care of the child. These parents probably do understand that there is lesser value in the choice that they made. Nevertheless, it is for them a much more convenient option when compared to an alternative which, in their eyes, is an arduous yet pointless task to undertake. There is also the issue of cost. It was only after the school offered to provide the students with free meals and the convenience of a bus ride home did these parents accept the idea of allowing their children to participate in the programme. 
On the issue of educational attainment in the current landscape, the question to pose to the more successful members of the Malay community is this: Do we wait for those trapped in the vicious cycle to demonstrate effort at helping themselves before we offer our hands to assist? Or do we show understanding and empathy by willingly reaching out to them and offering whatever help that can be rendered even if it is not asked for? The former is based on the belief that there should be equality of opportunity with the amount of assistance given only when personal effort is shown. The latter is based on the principal of equality of outcomes. It means going out of our way to understand the needs of the individual by identifying obstacles and offering the necessary resources to enhance their capacity to achieve the same outcomes as the rest of mainstream society. This is consciously done with the full understanding that these individuals lack the 'bandwith' to strive for opportunities to better their lives. The responsible choice for the Malay community should be for the latter.

This article is written in appreciation of the good work undertaken by Singapore's Malay organisations. It began by arguing that based on current demographic trends, the ethnic Singaporean Malay minority community is set to grow to become a more sizeable workforce compared to the other ethnic groups. It then rationalises on the need to maximise the future economic potential of this segment of the labour force by raising the academic achievements of its current cohort of students. From the perspective of the work of the Malay organisations, it then lists out the programmes which had been developed since the early 1980s. However, arguing that as well-intentioned as these programmes were set out to be, they have yet to deliver the promise of raising the academic achievement of the Malay community.

A recommendation is then made to build on the principles of integration and consolidation when looking at Malay students' participation in the available programmes. Specifically two models, the school-based wraparound approach and the conscientisation process were discussed. Though still to be fully implemented, it is hoped that the proposed models will go a long way in resolving the issue of academic underachievement of students from the community. Malay organisations must continue to galvanise the community while there is much enthusiasm and willingness among its members to help one another. Leaders of the ethnic group should continue picking out best practices to ensure that the educational attainment of the ethnic Malay minority community reaches parity with the rest in the country, if not better.

\section{Notes}

15 ' $O$ ' level passes is generally taken to be the benchmark for credible performance in the GCE ' $O$ ' level examination

2 The streaming process at the time involved 3 basic tracks. Based on their performance in the Primary School Leaving Examinations (PSLE), students are channeled respectively into the Express, Normal (Academic) and Normal (Technical) streams. Students who were not even able to qualify for these levels are channelled to the Institute of Technical Education (ITE) for a more vocationally-oriented education. A small number however, can still be retained if they are not able to meet the minimum standards.

3 In one activity, participants were instructed to pin on badges where stereotypical descriptions based on class and race were written. They were then made to discuss/debate/argue to see if these labels are justified. $4 \quad$ Although unpublished, the author cites statistics taken from Mendaki's outreach efforts from August to November 2003. (Primary One education in Singapore begins at age seven and the new academic year begins in January.) The scheme enrolled fifty-nine children aged six years who had not previously attended pre-school. They were registered into preschool centres for an intensive 2-month bridging programme. At the end of the programme, post-test scores indicated a 1-year gain in terms of the children's foundation skills. Nevertheless, despite their encouraging results, these children would still have entered Primary One with a learning deficit, albeit by a narrower margin. 


\section{References}

Ahmad, S. (2007). Embracing Education without Borders. Mendaki Policy Digest 2006. Singapore: Yayasan Mendaki, pp. 5-25.

Alatas, S.H. (1977). The Myth of the Lazy Native: A Study of the Image of the Malays, Filipinos and Javanese from the 16th to the 20th Century and Its Function in the Ideology of Colonial Capitalism. NY: Frank and Cass Company Ltd.

Aljunied, S.M.K. (2002). Making Sense of an Evolving Identity: A Survey of Studies on Identity and Identity Formation among Malay-Muslims in Singapore. Journal of Muslim Minority Affairs. 26(3), $371-388$.

AMP (1993 February 19). Rancang Luas Projek Dr Bola. Berita Harian, p.10.

Asiaone News (2007). PM Lee's speech at Mendaki's 25th anniversary dinner and awards presentation. (2007, September 2). Available at http://news.asiaone.com/News/AsiaOne\%2BNews/ Singapore/Story/A1Story20070902-23956.html. [Accessed on 5 March 2015].

Association of Muslim Professionals. (2006). Chairman's Message. Annual Report. Singapore: AMP, p. 2.

Association of Muslim Professionals. (2009). About Us. Available at http://www.amp.org.sg. [Accessed on 20 November 2009].

Association of Muslim Professionals. (2012). Demographic Study of Singapore Malays. Available at http://www.amp.org.sg/edisi/data/Publications/3rd\%20Convention\%20Journal/Section\%20 9\%20-\%20Demographic\%20Study.pdf. [Accessed on 10 February 2015].

Attorney-General of Singapore. (1965). Article 152 of the Constitution of the Republic of Singapore. Available at http://statutes.agc.gov.sg/non_version/cgi-bin/. [Accessed on 15 October 2009].

Bland, B. (2010). Singapore government dodges Malay education issue again. Asian Correspondent. Available at http://asiancorrespondent.com/. [Accessed on 6 March 2015].

Freire P. (1970). Pedagogy of the Oppressed (15 th ed.). NY: Seabury.

Giddens, A. (1991). Modernity and self-identity: Self and society in late modern age. CA: Stanford University Press.

Goy, P. (2013). 575 students under Singapore's four self-help groups presented with academic awards. Available at http://www.straitstimes.com/breaking-news/singapore/story/575-students-undersingapores-four-self-help-groups-presented-academic\#sthash.sh1NHiNh.dpuf. [Accessed on 5 February 2015].

Hodge, W. (2007). Basic Education Curriculum Revisited: A Look at the Current Content and Reform. Singapore: Ministry of Education.

Jamiyah. (2014). Lend-a-hand Project. Available at http://www.jamiyah.org.sg. [Accessed on 5 February 2015].

Juhari, M.S. (2012). Conscientising the Singaporean Malay-Muslim Youth: Experiences of MalayMuslim Youths Participating in Community Outreach Programmes. Saarbrücken: Lap Lambert Academic Publishing.

Lian, K. F. (2001). Construction of Malay Identity across Nations - Malaysia, Singapore, and Indonesia. Bijdragen tot de Taal-, Land- en Volkenkunde. 157 (4), 861-879.

Ministry of Education. (2006). Release of the 2006 Primary School Leaving Examination Results. Available at http://www.moe.gov.sg/press/2006.htm. [Accessed on 18 November 2009].

Ministry of Education. (2014). Release of 10-Year Trend of Educational Performance 2004 - 2013. Available at http://www.moe.gov.sg/media/press/files/2014/11/chart-d2-5-10year-trendeducational-performance-2004-2013.pdf. [Accessed on 4 May 2015].

Mokhtar, et. al (2012). The Malay Underclass. Singapore: Nanyang Technological Institute.

Mullainathan, S., \& Shafir, E. (2013). Scarcity: Why having too little means so much. NY: Macmillan.

Ong, A. (2014). Beware growing 'parentocracy': NIE don. Available at http://www.straitstimes.com/ breaking-news/singapore/story/beware-growing-parentocracy-nie-don-20140330. [Accessed on 2 February 2015]. 
Roehrig, A. D. et al. (2008). Mentoring beginning primary teachers for exemplary teaching practices. Teaching and Teacher Education, 24 (3), 684-702.

Singapore Department of Statistics. (2009). Population Trends 2009. Available at http://www.singstat. gov.sg. [Accessed on 3 March 2015].

Singapore Department of Statistics. (2010). Glossary. Available at http://www.singstat.gov.sg/docs/ default-source/default-document-library/publications/publications_and_papers/cop2010/ census_2010_release3/glossary.pdf. [Accessed on 5 March 2015].

Singapore Department of Statistics. (2015). Glossary. Available at http://www.singstat.gov.sg/docs/ default-source/default-document-library/publications/publications_and_papers/population_ and_population_structure/population2014.pdf. [Accessed on 5 March 2015].

Singapore 2025. (2011). Aljunied GRC: Pritam Singh - Rally Speeches. Available at https:// singapore2025.wordpress.com/2011/05/05/aljunied-grc-pritam-singh-rally-speeches/. [Accessed on 4 March 2015].

Suratman, S. (2004). "Problematic Singapore Malays" - The making of a portrayal. Available at http:// www.fas.nus.edu.sg/malay/publications/working_papers/Problematic\%20Singapore\%20 Malays.pdf. [Accessed on 4 March 2015].

Tan, J. (2010). Compulsory education in Singapore - who benefits? Asia Pacific Journal of Education. $30(4), 401-418$.

Vlieland, C. A. (1932). British Malaya: a report of the 1931 census and on certain problems of vital statistics. London: Crown Agents for the Colonies

Wee, D. (2007, September 3) Progress and prosperity for Malays, the Singapore way. The Straits Times, p. 20.

Yayasan Mendaki. (2007). Mendaki Policy Digest 2006. Research and Policy Department. Singapore: Yayasan Mendaki.

Yayasan Mendaki (2010). PRAXIS. Available at http://www.mendakiclub.org.sg/praxis/. [Accessed on 6 March 2015].

Yayasan Mendaki. (2015). Max Out: A Programme for Out-Of-School Youths. Available at http:// www.mendaki.org.sg/youth-in-action/max-out. [Accessed on 6 March 2015]. 